ISSN : $2302-1590$

E-ISSN: $2460-190 \mathrm{X}$

\author{
ECONOMICA
}

Journal of Economic and Economic Education Vol.3 No.1 (53 - 63)

\title{
ANALISIS FAKTOR DOMINAN YANG MEMPENGARUHI KEPUTUSAN MAHASISWA MELANJUTKAN PENDIDIKAN KE PROGRAM STUDI PIPS PASCASARJANA UNP
}

\author{
Vivina Eprillison \\ Dosen Program Studi Pendidikan Ekonomi STKIP- PGRI Sumbar \\ Jl. Gunung Pangilun No.1, Padang Sumatera Barat \\ Email : vi2na@yahoo.com \\ submited: 2014.05.18 reviewed:2014.07.16 accepted: 2014.10.30 \\ http://dx.doi.org/10.22202/economica.2014.v3.i1.236
}

\begin{abstract}
This research was aimed at revealing the dominant factors influencing the students' decision to continue their study to the Social Science Education Program of Graduate Program of Padang State University. The factors analyzed involved future income, cost of study, work opportunities in the future, social status, parents' education, intrinsic motivation and the National Education Departement policies. This research was a kind of survey using exploratory approach and factors analysis. The population of the research was all students took the Social Science Education Program of Graduate Program of Padang State University registered in period 2011. The result of the research showed that the dominant factors influencing the students' decision to continue their study to the Social Science Education Program of Graduate Program of Padang State University were the future income, bonus and work opportunities in the future. In addition, the cost of transportation during their study was higher than the cost of buying books \& photo copy which of course very important in continuing education to a higher level, especially at Post Graduate Program.

\section{Abstrak}

Penelitian ini bertujuan untuk mengetahui faktor-faktor dominan yang mempengaruhi keputusan mahasiswa melanjutkan pendidikan ke program studi PIPS Pascasarjana di Universitas Negeri Padang. Faktorfaktor yang diteliti tersebut meliputi faktor pendapatan di masa datang, biaya pendidikan, kesempatan kerja di masa datang, status sosial, tingkat pendidikan orang tua, motivasi intrinsik dan kebijakan Diknas. Jenis penelitian ini adalah survey dengan pendekatan eksploratoris serta menggunakan analisis faktor. Populasi dalam penelitian ini adalah semua mahasiswa program studi PIPS Pascasarjana Universitas Negeri Padang yang masih terdaftar pada periode tahun 2011.Hasil penelitian ini menunjukkan bahwa faktor dominan yang mempengaruhi keputusan mahasiwa melanjutkan pendidikan ke program studi PIPS Pascasarjana Universitas Negeri Padang adalah faktor pendapatan di masa datang khususnya pada item penghasilan di masa datang dan juga bonus, serta item pekerjaan pada faktor kesempatan kerja di masa datang. Selain itu juga ditemukan rata-rata biaya transportasi selama perkuliahan lebih tinggi dibandingkan dengan rata-rata biaya untuk pembelian buku \& fotokopi yang tentunya lebih dibutuhkan dalam melanjutkan pendidikan kejenjang yang lebih tinggi khususnnya pada program Pascasarjana.

Keywords : education, human capital
\end{abstract}

C2014 Prodi Pendidikan Ekonomi STKIP PGRI, Padang 


\section{PENDAHULUAN}

Pendidikan merupakan investasi sumber daya manusia jangka panjang dan mempunyai nilai strategis bagi kelangsungan peradaban manusia di dunia. Terkait hal ini, bangsa Indonesia menempatkan pendidikan sebagai sesuatu yang penting dan utama, sebagaimana terlihat pada pembukaan UUD 1945 yang menegaskan bahwa salah satu tujuan nasional bangsa Indonesia adalah mencerdaskan kehidupan bangsa.

Pendidikan mempunyai andil yang cukup besar terhadap pengembangan sumber daya manusia khususnya bangsa kita, dan hendaknya hal ini mendapat perhatian khusus dari pemerintah dalam rangka meningkatkan pertumbuhan ekonomi serta pengembangan sumber daya manusia. Berbagai upaya sudah dilakukan oleh pemerintah maupun masyarakat, ditujukan untuk mencerdaskan dan meningkatkan kualitas sumber daya manusia Indonesia. Peningkatan kualitas sumber daya manusia tersebut dapat dilakukan dengan meningkatkan mutu pendidikannya.

Peningkatan mutu pendidikan tersebut dapat dilakukan dengan cara peningkatan sumber daya manusianya yaitu salah satunya dengan cara melanjutkan pendidikan.Seseorang yang melanjutkan pendidikan pada perguruan tinggi khususnya tingkatan Pascasarjana, tentu saja akan berpikir ulang apakah dalam hal ini mereka memutuskan untuk melanjutkannya ataupun tidak sama sekali. Jika seseorang memutuskan untuk melanjutkan pendidikan tersebut, maka dalam hal ini mereka tentu saja harus memilih program studi yang sesuai dengan keinginan mereka.

Keputusan dalam melanjutkan pendidikan kejenjang yang lebih tinggi seperti strata dua, tentu saja seseorang tersebut melihat dari keunggulan masingmasing perguruan tinggi. Sebagaimana yang diketahui bahwa Universitas Negeri Padang merupakan salah satu perguruan tinggi yang ada di kota Padang. Pada universitas ini terdapat program pascasarjananya yang merupakan bagian integral universitas, dan kedudukannya setara dengan fakultas-fakultas dalam lingkungan universitas. Hal ini diperkuat lagi dengan visi program pascasarjana Universitas Negeri Padang adalah menjadi pusat keunggulan yang menghasilkan magister dan doctor yang berkualitas dan mampu bersaing dalam kajian bidang pendidikan, keilmuan, teknologi dan seni (IPTEKS) yang dilandasi oleh iman dan taqwa. Selain itu, misi program pascasarjana Universitas Negeri Padang adalah menghasilkan lulusan dalam berbagai bidang kajian dan IPTEKS yang mempunyai kompetensi dan komitmen untuk mengembangkan dan menerapkan ilmu dan keterampilan yang dimiliki kemaslahatan, kemanusiaan, bangsa dan negara

Pascasarjana (PPs) Universitas Negeri Padang yang terdiri dari beberapa program studi diantaranya yaitu administrasi pendidikan, pendidikan IPS, pendidikan bahasa, teknologi pendidikan, bimbingan konseling, ilmu lingkungan dan pendidikan dasar. Jika ditelusuri lebih mendalam pada program studi yang ada khususnya pendidikan IPS (PIPS), dapat kita ketahui bersama bahwa bidang ilmu ini merupakan bidang ilmu yang membahas beberapa aspek pengetahuan. Hal ini dapat dilihat dari konsentrasi yang terdapat pada program studinya yaitu konsentrasi pendidikan kewarganegaraan, sejarah, ekonomi / geografi, antropologi / sosiologi dan seni budaya.

Berdasarkan konsentrasi yang ada pada progam studi PIPS, tentu saja hal ini membuat keputusan mahasiswa melanjutkan pendidikan ke program studi PIPS Pascasarjana Universitas Negeri Padang mengalami perkembangan dari tahun ke tahun. Keadaan tersebut sejalan dengan kebijakan yang ditetapkan oleh Depdiknas (2009:35) pada pasal 54 ayat 2 yang 
menyatakan bahwa masyarakat dapat berperan serta sebagai sumber, pelaksana dan pengguna hasil pendidikan. Terkait dengan hal ini bagi mahasiswa yang merupakan bagian dari masyarakat luas, khususnya bagi mereka yang mengambil keputusan melanjutkan pendidikan S2 tentu saja dapat dikatakan bahwa mereka telah ikut berperan serta dalam pelaksanaan pendidikan khususnya dalam hal pengembangan sumber daya manusia ( human capital).

Fattah (2009:16) menjelaskan "pada dasarnya teori human capital yaitu suatu aliran pengeluaran yang menganggap bahwa manusia merupakan suatu bentuk kapital sebagaimana bentuk-bentuk kapital lainnya". Human capital ini dapat diaplikasikan melalui berbagai bentuk investasi SDM diantaranya pendidikan formal, pendidikan informal, pengalaman kerja, kesehatan, gizi serta transmigrasi.

Senada dengan pendapat sebelumnya, Yahya (2009:205) juga menjelaskan "human capital adalah kekayaan yang menghasilkan investasi terhadap orang, khususnya pendidikan formal dan pelatihan". Konsep human capital mengungkapkan bahwa manusia memiliki keterampilan, kebiasaan dan pengetahuan yang dapat dijual ke majikan dalam bentuk gaji atau upah resmi dan dapat diharapkan menjadi aliran pendapatan selama masa hidup seseorang seperti physical capital. Hal ini diperkuat lagi oleh pernyataan Todaro (2006:438) yang menjelaskan bahwa sebagai barang normal, orang akan "membeli" lebih banyak modal manusia (human capital) jika pendapatannya naik.

Blaug (Elfindri, 2001:20) "teori modal manusia menyatakan bahwa lamanya masa pendidikan dan semakin lamanyaakumulasi pengalaman berkorelasi positif dengan pendapatan". Individu yang memiliki pendidikan yang relatif lama memiliki pendapatan yang lebih tinggi bilamana dibandingkan dengan individu yang tidak memiliki pendidikan formal.

Selanjutnya Simanjuntak (1998:70) menjelaskan "asumsi dasar teori human capital adalah bahwa seseorang dapat meningkatkan penghasilannya melalui peningkatan pendidikan". Setiap tambahan satu tahun sekolah berarti, disatu pihak meningkatkan kemampuan kerja dan tingkat penghasilan seseorang, akan tetapi dipihak lain menunda penerimaan penghasilan selama satu tahun dalam mengikuti sekolah tersebut.

Todaro (2006:453) menjelaskan "dari sisi permintaan, ada dua hal yang paling berpengaruh terhadap jumlah atau tingkat pendidikan yang diinginkan yakni : (1) harapan bagi seorang siswa yang lebih terdidik untuk mendapatkan pekerjaan dengan penghasilan yang lebih baik pada sector modern dimasa yang akan datang (hal ini merupakan manfaat pendidikan individual / private benefits of education) bagi siswa dan / atau keluarganya, serta (2) biaya-biaya pendidikan baik yang bersifat langsung maupun tidak langsung yang harus dikeluarkan atau ditanggung oleh siswa dan / atau keluarganya". Selain itu, Todaro (2006:454) juga menjelaskan "ada beberapa variabel penting lainnya yang kebanyakan bersifat non ekonomi (misalnya pengaruh tradisi budaya, gender, status sosial, pendidikan orang tua dan besarnya anggota keluarga) yang sangat mempengaruhi permintaan terhadap pendidikan".

Sedangkan Irianto (2011:56)

menjelaskan "permintaan pendidikan perorangan secara agregat dipengaruhi oleh faktor-faktor antara lain pendapatan orang tua, pendidikan orang tua, pekerjaan orang tua, biaya pendidikan, kebijaksanaan umum (pemerintah), kebijaksanaan lembaga dan persepsi individu terhadap tiap-tiap jenis pendidikan". Permintaan pendidikan juga tergantung kepada cara pandangnya yaitu pendidikan itu dianggap sebagai konsumsi, 
sebagai investasi atau sebagai konsumsi dan investasi.

Card dan Krueger (dalam Irianto, 2011:68) juga menjelaskan "semakin tinggi kualitas pendidikan yang ditempuh semakin tinggi pula pendapatan yang didapatkannya, sebaliknya semakin rendah kualitas pendidikan yang diperolehnya semakin rendah pula pendapatannya". Hal ini mengindikasikan jika seseorang memutuskan untuk melanjutkan pendidikan kejenjang yang lebih tinggi, maka individu tersebut mengharapkan agar mendapatkan pendapatan (penghasilan) yang lebih tinggi di masa yang akan datang. Uraian di atas diperkuat oleh Fattah (2009:28) yang menjelaskan "salah satu indikator yang dijadikan dalam menentukan tingkat keberhasilan pendidikan yaitu besarnya penghasilan (gaji) yang diterima".

Terkait dengan adanya permintaan terhadap pendidikan terutama ketika proses mahasiswa melanjutkan pendidikan tersebut tentu berhubungan pula dengan biaya pendidikan. Cohn dkk (dalam Yahya, 2009:59) menjelaskan "biaya dalam pendidikan meliputi biaya langsung (direct cost) dan biaya tidak langsung (indirect cost)". Sehubungan dengan biaya pendidikan tersebut, maka dalam hal ini seseorang yang menggunakan biaya pendidikan mempunyai perencanaan kedepan untuk suatu tujuan hidup tertentu dengan biaya yang dikeluarkan dan diharapkan setelah lulus nantinya akan dapat memberikan manfaat atas segala biayabiaya yang telah dikeluarkan selama proses pendidikannya

Biaya langsung terdiri dari biayabiaya yang dikeluarkan untuk keperluan pelaksanaan pengajaran dan kegiatan belajar siswa berupa pembelian alat-alat pelajaran, sarana belajar, biaya transportasi, gaji guru, baik yang dikeluarkan oleh pemerintah, orang tua maupun siswa sendiri. Sedangkan biaya tidak langsung berupa keuntungan yang hilang (earning forgone) dalam bentuk biaya kesempatan yang hilang (opportunity cost) yang dikorbankan oleh siswa/mahasiswa selama belajar.

Biaya pendidikan tersebut nantinya akan terbayarkan ketika individu yang bersangkutan telah mendapatkan pekerjaan. Sebagaimana yang diketahui bersama bahwa setiap lulusan tenaga kerja terdidik akan bersaing untuk mendapatkan pekerjaan. Hal ini diperkuat oleh Elfindri (2001:60) yang menjelaskan "tingkat pengembalian individu semakin tinggi dengan semakin tingginya tingkat pendidikan".

Pengembalian individu terkait dengan semakin tingginya pendidikan yang dienyam oleh individu tersebut dapat dilihat pada kesempatan kerja yang akan mereka peroleh pada masa yang akan datang ketika mereka telah menyelesaikan pendidikannya. Pendidikan pada hakikatnya merupakan suatu hal yang penting dan tidak dapat dipisahkan dari kehidupan setiap individu, baik dalam kehidupan keluarga, masyarakat dan bangsa.

Tingginya pendidikan seseorang tersebut terkadang berdampak terhadap status sosial ekonominya. Sebagaimana yang dijelaskan oleh Muin (2006:85) "status sosial atau kedudukan sosial adalah suatu tempat atau posisi seseorang dalam kelompok sosial atau masyarakat secara umum sehubungan dengan keberadaan orang lain disekitarnya".

Senada dengan pendapat sebelumnya, Soekanto (2010:210) menjelaskan "kedudukan sosial artinya adalah tempat seseorang secara umum dalam masyarakatnya sehubungan dengan orang-orang lain, dalam arti lingkungan pergaulannya, prestisenya, dan hak-hak serta kewajiban-kewajibannya". Terkait dengan kedudukan sosial ini membuat adanya anggapan yang berlebihan dari masyarakat awam terkait dengan seseorang yang melanjutkan pendidikan ke jenjang yang lebih tinggi seperti strata dua (S2). 
Sebagaimana yang dijelaskan oleh Brubacher (dalam Danim, 2003:25) bahwa pendidikan sebagai suatu proses untuk mengembangkan potensi dasar manusia yang berkaitan dengan moral, intelektual dan jasmaninya untuk mencapai tujuan hidup dalam kerangka sistem sosial.Senada dengan pendapat sebelumnya Kamaluddin (1998:59) juga menjelaskan "pendidikan adalah berkenaan dengan pengembangan pengetahuan serta keahlian dan keterampilan dari manusia maupun tenaga kerja dalam proses pembangunan".

Berhubungan dengan kontribusinya yang sangat besar dalam pembangunan ekonomi, maka pendidikan dikatakan sebagai modal manusia (human capital), dan pengeluaran terhadap pendidikan penduduk disebut sebagai investasi dalam modal manusia (investment in human capital). Kemudian jika dikaitkan hal diatas dengan keputusan individu dalam memutuskan melanjutkan pendidikan, maka hal ini dapat diketahui bahwa orang tua ikut berperan serta dalam peningkatan kualitas individu yang bersangkutan.

Hal tersebut diperkuat oleh Makmum (2000:532) yang menjelaskan "orang tua dengan pendidikan yang tinggi akan lebih mungkin percaya bahwa keterlibatan mereka dalam pendidikan anaknya adalah penting". Selain adanya faktor tingkat pendidikan orang tua yang diduga mempengaruhi keputusan individu dalam melanjutkan pendidikannya, ada juga indikasi yang mengarah kepada motivasi yang berasal dari dalam individu tersebut. Perumusan masalah yang dikembangkan dalam penelitian ini adalah faktor-faktor apa saja yang dominan yang mempengaruhi keputusan mahasiswa melanjutkan pendidikan ke program studi PIPS Pascasarjana Universitas Negeri Padang khususnya dalam hal pengembangan sumber daya manusia (human capital) ?

\section{METODE PENELITIAN}

Penelitian ini menggunakan pendekatan kuantitatif melalui survey dengan pendekatan eksploratoris. Populasi dalam penelitian ini adalah mahasiswa program studi PIPS Pasacasarjana Universitas Negeri Padang dan terdaftar pada periode tahun 2011 berjumlah sebanyak 243 orang. Setelah dilakukan pengambilan sampel secara proportional stratified random sampling, maka didapatkan sampel secara keseluruhan adalah sebanyak 151 orang.

Data dalam penelitian ini dianalisis dengan menggunakan teknik analisis deskriptif dan analisis faktor. Analisis deskriptif digunakan untuk memberikan gambaran secara umum tentang variabel yang diteliti dengan cara menyajikan data kedalam tabel distribusi frekuensi. Kemudian dilakukan analisis persentase serta memberikan interpretasi terhadap analisis tersebut.

\section{PEMBAHASAN}

Tahap mereduksi terhadap faktor yang akan dianalisis dapat dilihat pada KMO and Bartlett's Test dan juga matriks korelasinya. Dalam hal ini terkait dengan nilai KMO and Bartlett's Test dapat dilihat pada tabel 1 berikut ini : 
Tabel 1. KMO and Bartlett's Test tahap I

Kaiser-Meyer-Olkin Measure of Sampling Adequacy.

Bartlett's Test of

Sphericity

Sumber : Olahan Data Primer, 2012

Berdasarkan pada Tabel 1 dapat diketahui nilai dari Kaiser Meyer Olkin Measure of Sampling Adequacy atau KMO (MSA). Dalam hal ini apabila nilai KMO berada diatas 0,5 , maka secara keseluruhan beberapa faktor yang ada pada analisis ini dapat diolah lebih lanjut. Dari tabel di atas juga dapat diketahui bahwa KMO pada penelitian ini sebesar 0,645>0,500 dan Bartlett's test of sphericity memiliki signifikansi sebesar $0,000<0,05$, maka hal ini mengindikasikan bahwa penelitian bisa dilanjutkan atau dengan kata lain bisa dianalisis lebih lanjut.

Selanjutnya terkait dengan matriks korelasinya, dimana matriks korelasi ini bertujuan untuk mengetahui apakah beberapa faktor yang ada tersebut memiliki korelasi yang erat antar sesamanya atau tidak sama sekali. Terkait dengan hal ini dapat dilihat pada tabel 2 berikut ini :

Tabel 2 : Anti Image Matrices tahap I

\begin{tabular}{lc}
\hline Faktor & Anti Image Correlation \\
\hline F 1.1 penghasilan & 0,690 \\
F 1.2 bonus & 0,654 \\
F 2.1 biaya langsung & 0,444 \\
F 2.2 biaya tidak langsung & 0,340 \\
F 3.1 pekerjaan & 0,681 \\
F 3.2 jabatan & 0,692 \\
F 3.3 kenaikan pangkat & 0,662 \\
F 4.1 achived status & 0,689 \\
F 5.1 tingkat pendidikan ayah & 0,509 \\
F 5.2 tingkat pendidikan Ibu & 0,499 \\
F 6.1 rasa senang dalam melanjutkan pendidikan S2 & 0,770 \\
F 6.2 kesungguhan dalam melanjutkan pendidikan S2 & 0,701 \\
F 6.3 semangat dalam melanjutkan pendidikan S2 & 0,722 \\
F 7.1 kebijakan diknas & 0,655 \\
\hline
\end{tabular}

Sumber : Olahan Data Primer, 2012

Berdasarkan tabel 2 di atas dapat diketahui bahwa Anti-Image Correlation beberapa faktor yang terkait dengan keputusan melanjutkan pendidikan ke jenjang $\mathrm{S} 2$ ada yang berkisar nilainya diatas 0,5 dan ada pula nilainya dibawah ketentuanterhadap AntiImage Correlation. Maka perlu dilakukannya pengujian ulang terhadap faktor yang nilainya di atas 0,5 yaitu : a) faktor pendapatan dimasa datang yang terdiri dari penghasilan dan bonus, b) faktor kesempatan kerja dimasa datang yang meliputi pekerjaan, jabatan dan kenaikan pangkat, c) status sosial meliputi achieved status, d) faktor motivasi intrinsik yang meliputi rasa senang, kesungguhan, dan 
semangat dalam melanjutkan pendidikan ke jenjang S2, d) faktor kebijakan Diknas.

Setelah dilakukan pengujian ulang pada tahap reduction ini, dapat diketahui bahwa nilai KMO mengalami peningkatan menjadi 0,750. Hal ini dapat dilihat pada Tabel 3 berikut ini :

Tabel 3 : KMO and Bartlett's Test tahap II

Kaiser-Meyer-Olkin Measure of Sampling Adequacy.

Bartlett's Test of Sphericity

Approx. Chi-Square

357.944

Df

Sig.

.000

Sumber : Olahan Data Primer, 2012

Berdasarkan pada Tabel 3 dapat diketahui bahwa nilai dari Kaiser Meyer Olkin Measure of Sampling Adequacy atau KMO (MSA) berada diatas 0,5, maka secara keseluruhan beberapa faktor yang ada pada analisis ini dapat diolah lebih lanjut. Dari tabel diatas juga dapat diketahui bahwa KMO pada penelitian ini sebesar 0,709>0,500 dan Bartlett's test of sphericity memiliki signifikansi sebesar $0,000<0,05$,maka hal ini mengindikasikan bahwa penelitian bisa dianalisis lebih lanjut.

Tabel 4: Anti Image Matrices tahap II

\begin{tabular}{lc}
\hline Faktor & Anti Image Correlation \\
\hline F 1.1 penghasilan & 0,682 \\
F 1.2 bonus & 0,653 \\
F 3.1 pekerjaan & 0,736 \\
F 3.2 jabatan & 0,706 \\
F 3.3 kenaikan pangkat & 0,746 \\
F 4.1 achieved status & 0,703 \\
F 6.1 rasa senang dalam melanjutkan pendidikan S2 & 0,839 \\
F 6.2 kesungguhan dalam melanjutkan pendidikan S2 & 0,702 \\
F 6.3 semangat dalam melanjutkan pendidikan S2 & 0,709 \\
F 7.1 kebijakan diknas & 0,623 \\
\hline
\end{tabular}

Sumber : Olahan Data Primer, 2012

Selanjutnya terkait dengan matriks korelasinya khususnya pada Anti-Image Correlation dapat dilihat pada Tabel 4 di atas. Pada tabel tersebut dapat diketahui bahwa Anti-Image Correlation kesemua faktor yang dilakukan pengujian ulang tersebut memiliki nilai di atas 0,5. Hal ini berarti kesembilan item faktor yang tersisa dapat dilakukan proses analisis faktor selanjutnya.Kemudian, pengolahan data dengan tahap communalities dapat dilihat penyajian datanya pada Tabel 5 berikut ini : 


\begin{tabular}{lcc}
\hline & Initial & Extraction \\
\hline F1.1_Penghasilan_dimasa_datang & 1.000 & .702 \\
F1.2_Bonus_dimasa_datang & 1.000 & .573 \\
F3.1_Pekerjaan & 1.000 & .657 \\
F3.2_Jabatan & 1.000 & .503 \\
F3.3_Kenaikan_pangkat & 1.000 & .500 \\
F4.1_Achived_status & 1.000 & .641 \\
F6.1_Rasa_senang_dlm_melanjutkan_pendidikan & 1.000 & .330 \\
& & .719 \\
F6.2_Kesungguhan_dlm_melanjutkan_pendidikan & 1.000 & \\
S2 & & .700 \\
F6.3_Semangat_dlm_melanjutkan_pendidikanS2 & 1.000 & .533 \\
\hline
\end{tabular}

Sumber : Olahan Data Primer, 2012

Berdasarkan Tabel 5 dapat diketahui bahwa sekitar 70,2\% varian dari penghasilan di masa datang yang dapat dijelaskan oleh faktor dominan yang nantinya akan terbentuk. Keadaan ini juga mengindikasikan bahwa korelasi faktor pendapatan di masa datang khususnya pada item penghasilan di masa datang dengan faktor yang lainnya relatif kuat, dimana sebesar 70,2\% mampu dijelaskan keterkaitan faktor ini dengan faktor yang lainnya

Dari Tabel 5 juga dapat diketahui bahwa sekitar $57,3 \%$ varian dari faktor item F1.2 dapat dijelaskan lebih lanjut oleh faktor dominan yang nantinya akan terbentuk. Keadaan ini mengindikasikan bahwa terjadinya korelasi yang kuat antara bonus pada faktor pendapatan di masa datang dengan faktor yang lainnya.Kemudian, pada Tabel 5 dapat diketahui juga bahwa sekitar $65,7 \%$ varian dapat dijelaskan nantinya oleh faktor dominan yang akan terbentuk, yang mana dalam hal ini item pekerjaan pada faktor kesempatan kerja di masa datang memiliki korelasi yang kuat dengan faktor yang lainnya.
Selanjutnya,dari Tabel 5 dapat diketahui juga bahwasekitar 50,3\% varian dari faktor item F3.2 dapat dijelaskan lebih lanjut oleh faktor dominan yang nantinya akan terbentuk. Keadaan ini mengindikasikan bahwa terjadinya korelasi yang kuat antara jabatan pada faktor kesempatan kerja di masa datang dengan faktor yang lainnya.

Pada Tabel 5 juga dapat diketahui bahwa sekitar $50 \%$ varian dari item kenaikan pangkat dapat dijelaskan oleh faktor dominan yang nantinya akan terbentuk. Keadaan ini juga mengindikasikan bahwa korelasi faktor kesempatan kerja di masa datang khususnya pada item kenaikan pangkat dengan faktor yang lainnya relatif cukup kuat, dimana sebesar 50\% mampu dijelaskan keterkaitan faktor ini dengan faktor yang lainnya.

Kemudian dapat diketahui juga nilai communalities faktor status sosial di masa datang khususnya pada item achieved status sebesar 0,641. Hal ini berarti bahwa sekitar $64,1 \%$ varian dapat dijelaskan nantinya oleh faktor dominan yang akan terbentuk, yang mana dalam hal ini item achieved status pada 
faktor status sosial memiliki korelasi yang kuat dengan faktor yang lainnya.

Pada Tabel 5 dapat diketahui juga bahwa hanya sekitar 33\% varian dari faktor item F6.1 dapat dijelaskan lebih lanjut oleh faktor dominan yang nantinya akan terbentuk. Keadaan ini mengindikasikan bahwa terjadinya korelasi yang lemah antara rasa senang dalam melanjutkan pendidikan pada faktor motivasi intrinsik dengan faktor yang lainnya.

Dari Tabel 5 dapat diketahui juga bahwa sekitar $71,9 \%$ varian dari faktor item F6.2 dapat dijelaskan lebih lanjut oleh faktor dominan yang nantinya akan terbentuk. Keadaan ini mengindikasikan bahwa terjadinya korelasi yang kuat antara item pada faktor ini dengan faktor yang lainnya.

Pada Tabel 5 juga dapat diketahui bahwa sekitar $70 \%$ varian dapat dijelaskan nantinya oleh faktor dominan yang akan terbentuk, dalam hal ini itemsemangat dalam melanjutkan pendidikan ke jenjang S2 memiliki korelasi yang kuat dengan faktor lainnya yang akan terbentuk. Selanjutnya dari Tabel 5 dapat diketahui juga bahwa sekitar $53,3 \%$ varian dari faktor ini dapat dijelaskan lebih lanjut oleh faktor dominan yang nantinya akan terbentuk. Keadaan ini mengindikasikan bahwa terjadinya korelasi yang relatif kuat antara item pada faktor ini dengan faktor lainnya

Tahap selanjutnya dalam analisis faktor adalah penentuan terhadap jumlah faktor yang akan terbentuk dari berbagai faktor yang telah ada. Terkait dengan penentuan jumlah faktor ini dapat dilihat dalam penyajian tabel 6 berikut ini

Tabel 6 : Total Variance Explained

\begin{tabular}{|c|c|c|c|c|c|c|c|c|c|}
\hline \multirow[t]{2}{*}{ Component } & \multicolumn{3}{|c|}{ Initial Eigenvalues } & \multicolumn{3}{|c|}{ Extraction Sums of Squared Loadings } & \multicolumn{3}{|c|}{ Rotation Sums of Squared Loadings } \\
\hline & Total & $\%$ of Variance & Cumulative \% & Total & $\%$ of Variance & Cumulative \% & Total & $\%$ of Variance & Cumulative \% \\
\hline 1 & 3.033 & 30.335 & 30.335 & 3.033 & 30.335 & 30.335 & 2.792 & 27.915 & 27.915 \\
\hline 2 & 1.762 & 17.622 & 47.957 & 1.762 & 17.622 & 47.957 & 1.942 & 19.422 & 47.337 \\
\hline 3 & 1.062 & 10.624 & 58.580 & 1.062 & 10.624 & 58.580 & 1.124 & 11.243 & 58.580 \\
\hline 4 & .922 & 9.222 & 67.802 & & & & & & \\
\hline 5 & .841 & 8.411 & 76.213 & & & & & & \\
\hline 6 & .676 & 6.758 & 82.971 & & & & & & \\
\hline 7 & .554 & 5.539 & 88.510 & & & & & & \\
\hline 8 & .464 & 4.645 & 93.155 & & & & & & \\
\hline 9 & .413 & 4.127 & 97.282 & & & & & & \\
\hline 10 & .272 & 2.718 & 100.000 & & & & & & \\
\hline
\end{tabular}

Berdasarkan Tabel 6 diatas dapat diketahui bahwa terdapat tiga faktor yang memenuhi ketentuan eigenvalues yang ada, sehingga dengan adanya hal ini menjadi faktor yang dominan mempengaruhi mahasiswa dalam melanjutkan pendidikan kejenjang yang lebih tinggi khususnya pada program Pascasarjana. Dari tabel tersebut didapatkan bahwa faktor pendapatan di masa datang khususnya pada penghasilan di masa datang, bonus serta pekerjaan memiliki nilai eigenvalues diatas angka satu,. Sehingga hal ini mengindikasikan bahwa ketiga faktor tersebut menjadi faktor yang dominan mempengaruhi keputusan mahasiswa dalam melanjutkan pendidikan ke Program Pascsarjana yaitu sebesar 30,33\%, , 17,62\% dan $10,62 \%$.

\section{PENUTUP}

Berdasarkan hasil penelitian ditemukan hal sebagai berikut :

1. Penghasilan dan bonus pada faktor pendapatan di masa datang serta 
pekerjaan pada faktor kesempatan kerja di masa datang merupakan faktor dominan yang terbentuk, dan ketiga faktor ini mempengaruhi keputusan mahasiswa prodi PIPS Pascasarjana UNP dalam melanjutkan pendidikannya.

2. Biaya pendidikan, tingkat pendidikan orang tua serta kebijakan Diknas tidak menjadi faktor dominan yang mempengaruhi keputusan mahasiswa dalam melanjutkan pendidikan ke jenjang yang lebih tinggi khususnya pada program Pascasarjana.

3. Item jabatan dan kenaikan pangkat pada faktor kesempatan kerja di masa datang setelah dilakukan penganalisaan menggunakan analisis faktor hanya termasuk kepada faktor yang pertama saja yaitu faktor penghasilan di masa datang, kemudian status sosial di masa datang termasuk ke dalam faktor dominan ketiga yang terbentuk yaitu pada item faktor pekerjaandan semangat serta kesungguhan dalam melanjutkan pendidikan pada faktor motivasi intrinsik ternyata termasuk kedalam faktor pertama yang terbentuk yaitu faktor penghasilan di masa datang.

Hasil penelitian mengenai faktor dominan yang mempengaruhi keputusan mahasiswa program studi PIPS Pascasarjana Universitas Negeri Padang memberikan dampak yang positif bagi berbagai pihak khususnya mahasiswa yang melanjutkan pendidikan tersebut. Yang mana dengan melihat hasil temuan tersebut bisa lebih memacu mahasiswa agar lebih termotivasi lagi dalam melanjutkan pendidikan, serta lebih menginstropeksi diri lagi dalam berbagai hal misalnya bisa lebih mengatur lagi pengeluaran yang berkaitan dengan biaya pendidikan terutama bisa meminimalisir biaya langsung khususnya rata-rata biaya transportasi. Dengan demikian mahasiswa lebih bisa meningkatkan pembelian terhadap buku maupun fotokopi yang berkaitan dengan materi perkuliahan.

Selain itu, dengan adanya penelitian ini diharapkan bagi semua pihak khususnya mahasiswa yang melanjutkan pendidikan strata duanya bisa lebih mengaplikasikan lagi ilmunya pada dunia pendidikan. Dengan demikian, pengembangan sumber daya manusia dapat tercapai dengan baik.

Berdasarkan hasil analisis data, kesimpulan dan implikasi dalam penelitian ini, maka dapat dikemukakan beberapa saran diantaranya yaitu :

1. Pascasarjana UNP hendaknya lebih banyak menambah lagi jurusan yang dibutuhkan oleh lingkungan kerja pada saat ini.

2. Pascasarjana UNP hendaknya lebih menyaring lagi mahasiswa yang ingin melanjutkan pendidikan ke strata dua (S2), sehingga nantinya bisa lebih meminimalisir sikap mahasiswa yang tersebut agar tidak hanya sekedar ikutikutan saja dalam melanjutkan pendidikannya.

3. Dinas Pendidikan hendaknya lebih meningkatkan lagi dalam reformasi kerja terutama bagi tenaga pengajar yang melanjutkan pendidikan S2, sehingga nantinya bisa meminimalisir sikap mahasiswa tersebut agar tidak hanya sekedar ingin mendapatkan prestise baik dari masyarakat maupun teman sejawat.

\section{DAFTAR PUSTAKA :}

\subsection{2/economica.2014.v3.i1.236}

Danim, Sudarwan. 2003. Ekonomi Sumber Daya Manusia. Jakarta : Pustaka Setia

Depdiknas. 2008. UU No.20tahun 2003 tentang Sistem Pendidikan Nasional. Jakarta : Sinar Grafika 
Djojohadikusumo, Sumitro. 1994. Dasar Teori Pertumbuhan dan Ekonomi Pembangunan. Jakarta : LP3ES

Elfindri. 2001. Ekonomi Sumber Daya Manusia. Padang : Universitas Andalas

Fattah, Nanang. 2009. Ekonomi dan Pembiayaan Pendidikan. Bandung : Remaja Rosda Karya

Irianto, Agus. 2011. Pendidikan sebagai Investasi dalam Pembangunan Suatu Bangsa. Jakarta : Kencana Pranada Media Group

Kamaluddin, Rustian. 1998. Pengantar Ekonomi Pembangunan. Jakarta :Lembaga Penerbit Fakultas Ekonomi Universitas Indonesia

Muin, Idianto. 2006. Sosiologi SMA/MA. Jakarta : Erlangga
Pascasarjana Universitas Negeri Padang. 2009. Buku panduan Program Magister (S2). Padang

Simanjuntak, Payaman. 1998. Pengantar Ekonomi Sumber Daya Manusia. Jakarta: Lembaga Penerbit Fakultas Ekonomi Universitas Indonesia

Simamora, Bilson. 2005. Analisis Multivariat Pemasaranan.Jakarta : PT.Gramedia Pustaka Utama

Soekanto, Soerjono. 2010. Sosiologi Suatu Pengantar. Jakarta : Rajagrafindo Persada.

Yahya. 2009. Ekonomi dan Pembiayaan Pendidikan. Padang : Sukabina Offset

Todaro, Michael.P. 2006. Pembangunan Ekonomi Jilid 1 Edisi Kesembilan. Jakarta : Erlangga 